\title{
Muscles and Morals: Spartacus, Ancient Hero of Modern Times
}

Tröhler, Margrit ; Späth, Thomas

Posted at the Zurich Open Repository and Archive, University of Zurich ZORA URL: https://doi.org/10.5167/uzh-82382

Book Section

Published Version

Originally published at:

Tröhler, Margrit; Späth, Thomas (2013). Muscles and Morals: Spartacus, Ancient Hero of Modern Times. In: Renger, Almut-Barbara; Solomon, Jon. Ancient Worlds in Film and Television. Gender and Politics. Leiden: Brill, 41-63. 


\title{
Ancient Worlds in Film and Television
}

\author{
Gender and Politics
}

\author{
Edited by
}

Almut-Barbara Renger and Jon Solomon

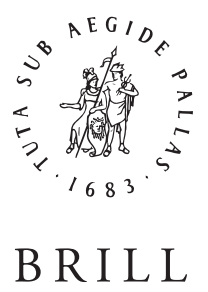

LEIDEN • BOSTON

2013

(C) 2013 Koninklijke Brill NV ISBN 978-90-04-18320-9 


\section{CONTENTS}

Introduction

Almut-Barbara Renger and Jon Solomon

\section{HistoricAl ANCIENTS}

Ben-Hur and Gladiator: Manifest Destiny and the Contradictions of American Empire

Jon Solomon

Muscles and Morals: Spartacus, Ancient Hero of Modern Times

Thomas Späth and Margrit Tröhler

With Your Shield or On It: The Gender of Heroism in Zack

Snyder's 300 and Rudoph Maté's The zoo Spartans

Thorsten Beigel

"This is Sparta!": Discourse, Gender, and the Orient in Zack

Snyder's 300

Jeroen Lauwers, Marieke Dhont and Xanne Huybrecht

"Everybody Loves a Muscle Boi": Homos, Heroes, and Foes in

Post-9/11 Spoofs of the 300 Spartans

Ralph J. Poole

The Womanizing of Mark Antony: Virile Ruthlessness and

Redemptive Cross-Dressing in Rome, Season Two

Margaret M. Toscano

Cleopatra's Venus

Elisabeth Bronfen

(C) 2013 Koninklijke Brill NV ISBN 978-90-04-18320-9 


\section{Mythological Ancients}

Over His Dead Body: Male Friendship in Homer's Iliad and Wolfgang Petersen's Troy (2004) Andreas Krass

Models of Masculinities in Troy: Achilles, Hector and Their Female Partners

Celina Proch and Michael Kleu

"Include me out" - Odysseus on the Margins of European Genre Cinema: Le Mépris, Ulisse, L'Odissea

Christian Pischel

Between Mythical and Rational Worlds: Medea by Pier Paolo

Pasolini

Lada Stevanović

“Universal's Religious Bigotry Against Hinduism": Gender Norms and Hindu Authority in the Global Media Debate on Representing the Hindu God Krishna in Xena: Warrior Princess Xenia Zeiler

\section{Mythological and Historical Thematics}

Ancient Women's Cults and Rituals in Grand Narratives on Screen: From Walt Disney's Snow White to Olga Malea's Doughnuts with Honey Svetlana Slapšak

Pandora-Eve-Ava: Albert Lewin's Making of a "Secret Goddess" ..... 271 Almut-Barbara Renger

Phryne Paves the Way for the Wirtschaftswunder: Visions of Guilt and "Purity" Fed by Ancient Greece, Christian Narrative, and Contemporary History Barbara Schrödl 
The New Israeli Film Beruriah: Between Rashi and Talmud, between Antiquity and Modernity, between Feminism and Religion

Index 


\title{
MUSCLES AND MORALS: SPARTACUS, ANCIENT HERO OF MODERN TIMES
}

\author{
Thomas Späth and Margrit Tröhler
}

"Spartacus": for political historians the name calls to mind the Spartacus League, the German Revolution of 1918, and its leaders Rosa Luxemburg and Karl Liebknecht; dance enthusiasts will associate the name with Aram Khatchaturian and the music he arranged for his ballet Spartak; scholars of ancient history will be reminded of the writings of Plutarch and Appian and of the slave revolt that lasted from 73 to $71 \mathrm{BC}$; and connoisseurs of popular literature will recall the novels of Lewis Grassic Gibbon, Arthur Koestler, and Howard Fast. ${ }^{1}$ Today, however, "Spartacus" probably evokes neither political nor musical nor historical events or texts but an image. For this is the man with that determined look emanating from steely blue eyes, a face featuring a classical straight nose beneath which lies a square chin with a conspicuous dimple, and a body sporting muscular naked arms and thighs. For many, "Spartacus" is Kirk Douglas, the American actor starring in Stanley Kubrick's Spartacus (1960) in one of his best-known roles (see Figure 1).

When the image of the actor becomes superimposed on a historical figure, we encounter a problem that Jean-Louis Comolli aptly described more than thirty years ago as le corps en trop or "a body too many." Using the example of Spartacus, our essay sets out to verify Comolli's hypothesis in films set in classical antiquity. We proceed from the construction of heroes in the theater and literature to the representation of muscular male bodies in the twentieth century. The bulging upper arms of the muscular heroes starring in the Spartacus films by Vidali (1913), Freda (1953), Kubrick (1960), Corbucci (1963), Dornhelm (2004), and DeKnight (2010) point toward the polysemy of popular culture. The latter uses and transforms

${ }^{1}$ Howard Fast, Spartacus (New York: n.p., 1951); Arthur Koestler, The Gladiators (trans. Edith Simon; London: J. Cape, 1939); Lewis Grassic Gibbon, Spartacus (London: Jarrold, 1933).

2 Jean-Louis Comolli, "La fiction historique: un corps en trop," Cahiers du cinéma 278 (1977) $5^{-16}$. Although the title of the English translation (see bibliography) is "A body too much," we use the grammatically correct "A body too many" as well.

(C) 2013 Koninklijke Brill NV ISBN 978-90-04-18320-9 


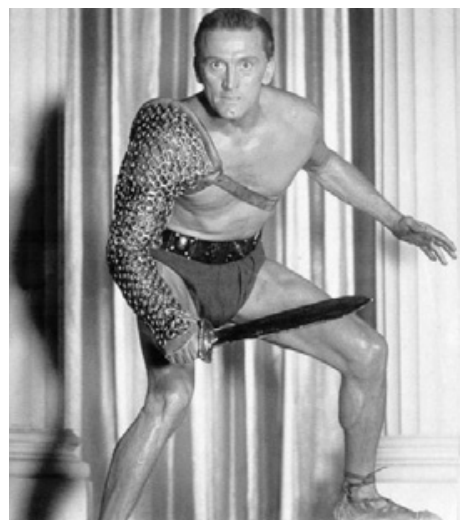

Figure 1 Kirk Douglas as Spartacus in Stanley Kubrick's Spartacus (studio photograph)

"the myth of antiquity" just as ancient cultures employed their myths as the stuff from which stories for the present were shaped.

\section{A Body Too Many? Initial Premise}

In 1977, Jean-Louis Comolli published an essay in which he claimed that characters in historical films always have "a body too many": the body of the actor, who avails himself of the character's imaginary and actualizes it as his own attribute, clashes with the culturally transmitted, albeit also changeable image, of the historical person, no matter how diffuse or eclectic this may be. In addition, following Ernst H. Kantorowicz, who distinguishes the "body natural" of the king from his "body politic", we can generally assume for historical persons a symbolic body as a persona ficta. ${ }^{3}$ Already during its lifetime, a body image is created for this symbolic body by all kinds of texts and iconographies. This image exists beyond the death of the natural body. Transmitted and transformed, it gives evidence of (in the sense of rendering visible) the immortal body politic of the persona ficta. The persona ficta in turn is rendered concrete in ever new texts and imagery up to the "living photography" of twentiethcentury cinema. A film, even by its title alone, may already evoke this persona by its name, which carries with it a political iconography and the

3 Ernst H. Kantorowicz, The King's Two Bodies. A Study in Mediaeval Political Theology (Princeton: Princeton University Press, 1957) 5 .

(C) 2013 Koninklijke Brill NV ISBN 978-90-04-18320-9 
popular knowledge imparted by novels and high-school history. Besides, this "body fiction," which mostly exists in exchanges between different media, is given historical reference. 4 The only "real" body - whose "reality" in the cinema has nevertheless always been imaginary, since it is conveyed by the medium - is the actor's. Comolli argues that the actor's body doubles the historical body, and thereby competes with the body fiction. Thus, the characters appearing in historical films always leave room for ambiguity among the audience. Consequently, a "disbelief" in the fiction persists, since there is "a body too many" - the actor's. ${ }^{5}$

Extending Comolli's hypothesis, the actor's body can be said to represent an empty mask for the film character at best only at the beginning of the fiction. On the one hand, the actor brings along his own body image and quasi-physical presence, which he realizes through his acting (and which thus leads back to a casting decision). On the other, as soon as he is reasonably popular, the actor also carries his own sociocultural image (arising from previous roles and general information about his "person" as a celebrity) into the film; such a symbolic media body, as it were, further intensifies the actor's imaginary shadow boxing with the historical prototype. 6

However, various possibilities for dynamizing, and thus shaping, the historical figure also exist within cinematic representation. Comolli demonstrates how Pierre Renoir's performance in Jean Renoir's La Marseillaise (1938) renders fruitful the remoteness of Louis XVI's symbolic body, especially in how the actor exhibits the character's body and presents it as problematic, since the character cannot measure up to the symbolic role. Ultimately, the king's body - the body politic - becomes too much.

4 Following Kantorowicz, who speaks of the "mystic fiction" of the king's two bodies, Hans Belting introduces the term "body fiction"; Bild-Anthropologie: Entwürfe für eine Bildwissenschaft, (München: W. Fink, 2001) 97-98. However, he employs it more concretely than we do here, namely, as an image of the king in the shape of an effigy used in cultic contexts. On the popular knowledge arising from high-school history and which evokes historical subjects and figures, see Michèle Lagny, "Popular Taste: The Peplum," Richard Dyer and Ginette Vincendeau, eds., Popular European Cinema (London: Routledge, 1992). In his study of the marketing of epic films in general and Spartacus in particular, Martin M. Winkler, "'Culturally Significant and Not Just Simple Entertainment': History and the Marketing of Spartacus," in Winkler, ed., Spartacus. Film and History (Malden, MA; Blackwell, 2007) 198-232, esp. 210-222, provides interesting insights into the advertising materials addressed to high-school teachers.

5 Comolli, "La fiction historique: un corps en trop," 6.

6 On the many-layered construction of feature film characters, see Margrit Tröhler and Henry M. Taylor, "De quelques facettes du personnage humain dans le film de fiction," Iris 24 (1997) 33-57.

\section{(C) 2013 Koninklijke Brill NV ISBN 978-90-04-18320-9}


Its abolition thus seems plausible in both diegetic and historical terms. Here, the actualization of the historical figure by the mise-en-scène and by the actor manages to realize the historical material, and to lend it new explosive force at the time of the Front populaire. ${ }^{7}$

Comolli's hypothesis holds true to a certain extent for all historical film characters. We argue, however, that films set in classical antiquity, and Spartacus in particular, present a somewhat different case. The popular imagination conceives antiquity largely as a fictional construct, the referential weight of which confers upon the theme and characters a touch of authenticity and continuous cultural tradition. Iconographically speaking, reasonably clearly drawn body fictions exist for only some very few "great" historical figures like Augustus, Nero, Julius Caesar, or Cleopatra. ${ }^{8}$ Their iconography has survived since antiquity, becoming absorbed and transformed over time by actualizations in historical painting, in stage plays whose plots are set in ancient history, and in the film performances by many different actors. What emerges here is the tension between the body fiction, in the above sense, and the "corps en trop," namely, when one of the body images becomes predominant, for instance Elizabeth Taylor's as Cleopatra or Peter Ustinov's as Nero.

For the majority of ancient figures, however, a new tension arises, because no ancient body fiction can be made out. Twentieth-century actors thus shadow box with a symbolic body that is a modern construction from the outset - albeit one that stakes a claim to ancient referentiality. Spartacus exemplifies this point, since he possesses no ancient symbolic body in terms of the above "body fiction." Nevertheless, we argue that a symbolic body of Spartacus did indeed exist - but, however paradoxical it may sound, this body image emerged as a modern hero's, which began its life only in the eighteenth century. ${ }^{9}$ Seen thus, Comolli's hypothesis needs to be fundamentally questioned, or rather expanded and reformulated. If we understand history as the appropriation of history by the "dialectical image," in Walter Benjamin's terms, that is, as an ever-changing construc-

7 Jean Renoir, Écrits 1926-1971 (Paris: P. Belfond, 1974) himself mentions that La Marseillaise was meant to be neither a historical nor a modern film, but quite simply a "timely" film.

8 Michèle Lagny, "Dans les pas d'Achille et d'Alexandre," in Tomas Lochman, Thomas Späth, and Adrian Stähli, eds., Antike im Kino: auf dem Weg zu einer Kulturgeschichte des Antikenfilms (Basel: Verlag der Skulpturhalle Basel, 2008) 202-209, comments on the missing "portrait" of Achilles.

9 See Lorna Hardwick, Reception Studies (Oxford: Published for the Classical Association, 2003) $5^{-11}$, for a discussion of the reception and its various modes of adaption, appropriation, refiguration, transposition, etc.

(C) 2013 Koninklijke Brill NV ISBN 978-90-04-18320-9 
tion that places one image of the past over another, ${ }^{10}$ then no "historical persons" with quasi-fixed "body fictions" tied to a past reality can exist.

For this reason, it is precisely the films set in classical antiquity that can help us understand that historical bodies emerge only from the manifold adaptations and transformations involved in reception: they allow us to trace how exchanges among different media continuously bring forth and alter body fictions. Thus, the body of Massimo Girotti in Freda's Spartaco (1953) is "en trop (too much)" in relation to the symbolic body of Mario Guaita in Vidali's Spartaco, il gladiatore della Tracia (1913); Kirk Douglas's sheer physicality in Kubrick's Spartacus (1960) in turn transforms Girotti's body fiction, and is itself then taken up and to a certain extent formed over again by Goran Visnjic's Spartacus in Dornhelm's television mini-series Spartacus (2004), and his by Andy Whitfield's in Spartacus: Blood and Sand (2010), and so on. ${ }^{11}$ We will begin testing our hypothesis by examining the "dramaturgical constants" or "transversal" meanings that pervade the various constructions of the body fiction, and then we will consider the range of meanings of Spartacus' body fiction in cinema since the 1910 .

\section{Spartacus Before the Twentieth Century}

No hero by the name of "Spartacus" existed in antiquity. While his name occurs in extant texts from Sallust to Appian, Plutarch, and Florus, ${ }^{12}$ Spartacus is not assigned heroic status in a modern sense, that is, as an

10 Walter Benjamin, "Über den Begriff der Geschichte," in Siegfried Unseld, ed., Illuminationen. Ausgewählte Schriften (Frankfurt am Main: Suhrkamp, 1977) 251-263. See also Detlev Schöttker, "Benjamins Bilderwelten. Objekte, Theorien, Wirkungen," in idem (ed.), Schrift, Bilder, Denken. Walter Benjamin und die Künste (Frankfurt am Main: Suhrkamp, 2004) 10-31, esp. 25-26.

${ }_{11}$ We also understand Spartacus as a myth in this sense, just as the image of Rome in films set in classical antiquity in general. Our approach here follows Peter Bondanella, The Eternal City: Roman Images in the Modern World (Chapel Hill: University of North Carolina Press, 1987) 1, who speaks of the "myth of Rome." He notes that the "myth is not so much a relic to be venerated as it is a flexible and limitless source for self-expression, a common heritage which has met the needs of successive generations, influenced the styles of different periods, and inspired widely different forms of artistic expression."

12 Appian, Civil War, 1.14 (116-120); Plutarch, Crassus, 8-11, Comparatio Nicias-Crassus 3.2, Pompeius 21.1-4, Cato minor 8.1-2; Florus, Epitome de Tito Livio, 2.8; Sallust, Hist. 3 fr. 90-94, 96-102, 106; Hist. 4 fr. 22-23, 25, 30-33, 37, 40-41. On these passages and other, less detailed ones, see Brent D. Shaw, Spartacus and the Slave Wars. A Brief History with Documents (Boston, MA: Bedford/St. Martin's, 2001) 130-165. On the literary sources, see also "Appendix I" in Keith Bradley, Slavery and Rebellion in the Roman World, 140 B.C.-70 B.C. (Bloomington: Indiana University Press, 1989) 133-139. The "Principal Ancient Sources on Spartacus" are also available in an English translation in Winkler, Spartacus, 233-247.

\section{(C) 2013 Koninklijke Brill NV ISBN 978-90-04-18320-9}


exemplary figure. In Roman culture heroes are exemplary "great men" who embody the prevailing social norms. These norms can be fulfilled only by members of the Roman aristocracy, from whose actions the exempla were composed, that is, those small stories that function as the cogwheels and transmission belts of social memory, which in turn determine and convey the dominant norms. ${ }^{13}$ Given their social and legal status, slaves could thus be neither "great men" nor, by further extension, heroes. Even as wartime enemies, slaves were not considered equals: a Roman general who defeated unworthy enemies like slaves could not, as was customary, celebrate his victory as a triumph, but at most reckon with the less significant ovatio. ${ }^{14}$ Most surviving texts documenting the so-called "slave war"15 waged under Spartacus do not consider this war honorable, nor do they describe him as an enemy commander. The slave war, morever, is merely one episode in a series of external and internal threats during a century of civil wars extending from ca. 130 to 30 вс. ${ }^{16}$ Only Plutarch's biography of Crassus, who was given command against Spartacus, establishes the slave leader as one of the Roman general's adversaries. Plutarch thus renders tangible a few anecdotes shaping an ancient image of Spartacus around 170 years after the events. However, this by no means establishes Spartacus as an ancient hero. ${ }^{17}$

13 For a more detailed discussion, see Thomas Späth, "Faits de mots et d'images. Les grands hommes de la Rome ancienne," Traverse 5 (1998) 35-56, and Marianne Coudry and Thomas Späth, L'invention des grands hommes de la Rome antique. Die Konstruktion der grossen Männer Altroms. Actes du colloque du Collegium Beatus Rhenanus (Paris: Collections de l'Université Marc Bloch - Études d'archéologie et d'histoire ancienne, 2001), including numerous references to discussions on the problem of the "great men."

14 See Aulus Gellius 5.6.20-21.

15 The slaves seem to have considered their revolt less a "war" than a struggle for freedom; for a discussion of the aims of the revolt, see Bradley, Slavery and Rebellion in the Roman World, 98-125. For a description and characterization of Spartacus in terms of historical events, see the concise comparative survey of ancient texts in Alison Futrell, "Seeing Red. Spartacus as Domestic Economist," in Sandra R. Joshel, Margaret Malamud, and Donald T. McGuire, Jr., eds., Imperial Projections: Ancient Rome in Modern Popular Culture (Baltimore: The Johns Hopkins University Press, 2001) 80-81.

16 The series of belligerent events includes, among others, the war against Jugurtha in Numidia from 112 to 105; the invasions of Germanic peoples (Cimbri, Teutons) in northern Italy from 113 to 101, and the related ascent to power of Marius; the so-called Social War from 91 to 88; the war against Mithradates from 87 to 83, and again from 74 to 64; Sulla's march on Rom in 88 and 83/82, and his subsequent dictatorship from 82 to 79 ; the revolt of Sertorius in Spain from 79 to 71 ; the campaigns against the sea pirates from 74 to 71 under the leadership of M. Antonius and in 67 under Pompeius; and the so-called Catilinarian Conspiracy in 63. The slave revolt under Spartacus occurred between these events from 73 to 71; both Crassus and Pompeius sought to take credit for its suppression.

17 See Plutarch (Crassus 8.3) for positive epithets on Spartacus. Nevertheless, positive appraisals fail to constitute a hero in themselves: Sallust (Hist. 3. fr. 91) also characterizes 
From the fifth century, Spartacus as a real historical figure passes unnoticed as a historical actor for about thirteen centuries ${ }^{18}$ - his name is mentioned at best in passing in histories of Rome. Only from the mid-eighteenth century does a heroic Spartacus begin to emerge. The number of pages allotted to us cannot accommodate a full chronological survey of how Spartacus was constructed as a hero from the eighteenth to the twentieth centuries, so we will simply summarize our findings here: in the Enlightenment, Spartacus became a heroic fighter for the general human right to individual freedom; in the nineteenth century, Spartacus as slave leader became a champion of national self-determination for ethnically-linguistically constituted peoples; and in the twentieth century he became a socialist hero of the struggle for liberation of the oppressed against their oppressors. ${ }^{19}$

\section{A Hero for the Cinema Audience: Spartacus's Career in the $1960 \mathrm{~s}$}

Massimo Girotti's actualization of the "body fiction of Spartacus" established an exciting relationship between Riccardo Freda's Spartaco (1953) and the range of meanings supplied by literature, the theater, and earlier films set in classical antiquity in general, and particularly by Giovanni Enrico Vidali's Spartaco (1913). What emerged here was a historical body, the image of a heroic slave of Greco-Roman antiquity, a muscle-bound figure who fights against oppression. The image models Freda's Spartaco, to which Stanley Kubrick's Spartacus would subsequently refer.

Howard Fast's novel provided both the basis and the starting point for what is probably the best known film about Spartacus. ${ }^{20}$ He presented a blatantly obvious contrast between the morally reprehensible Romans and the exemplary slaves as antagonist classes. Alison Futrell has offered a convincing analysis of how the novel opposes slaves and Romans in terms of "life" versus "death," collective group consciousness versus an individual and hedonistic craving for power, country versus city, and good

Spartacus as ingens ipse virium atque animi ("of excellent power and spirit"), without him subsequently occupying more than an episodic function in historiography. The descriptions in Appian and Florus are similar in this respect.

18 The last known reference to our best knowledge occurs in Orosius 5.24.1-8, 18-19. See Shaw, Spartacus and the Slave Wars, 19.

19 For this, see Thomas Späth and Margrit Tröhler, "Spartacus - Männermuskeln, Heldenbilder oder: die Befreiung der Moral," in Lochman, Späth, and Stähli, Antike im Kino, 170-193.

20 On Fast, a bestselling author since the 1930s and a member of the Communist Party of the United States from 1943 to 1957, see Futrell, "Seeing Red. Spartacus as Domestic Economist," 90-91.

\section{(C) 2013 Koninklijke Brill NV ISBN 978-90-04-18320-9}


heterosexual-monogamous patriarchal order versus bisexual-depraved indiscipline. ${ }^{21}$ Fast's comments on the genesis of the novel in his autobiography are revealing in terms of explaining this popular-communist viewpoint: while imprisoned, he had busied himself with German history during the interwar period, first intending to write a book about Rosa Luxemburg and her leading role in the Spartacus League, but eventually turning to the Spartacus material. ${ }^{22}$

Kirk Douglas was enthusiastic about Fast's novel. One of America's most successful actors at the time, Douglas had acted in a number of historical films, most recently as Odysseus in Ulysses (1954). ${ }^{23}$ Douglas was born to a family of Russian Jewish immigrants in a suburb of New York. Writing in his autobiography, he describes his reaction to reading Fast's Spartacus as follows: 24

Spartacus was a real man, but if you look him up in history books, you find only a short paragraph about him. Rome was ashamed; this man had almost destroyed them. They wanted to bury him. I was intrigued with the story of Spartacus the slave, dreaming the death of slavery, driving into the armor of Rome the wedge that would eventually destroy her. I'm always astounded by the impact, the extent of the Roman Empire. Caesarea, Israel - full of Roman ruins.... Looking at these ruins, and at the Sphinx and the pyramids

21 Ibid., 90-97.

22 Howard Fast, Being Red (Boston: Houghton Mifflin, 1990), quoted in ibid., 91. Fast refers to C. Osborne Ward, The Ancient Lowly: A History of the Ancient Working People from the Earlies Known Period to the Adoption of Christianity by Constantine (Chicago: C.H. Kerr, 1907) as an essential source of information - which had been given to him by Communist officials for the purposes of ideological training. While Fast had not read Rafaello Giovagnoli's popular historical novel Spartaco (1874), he might have known the novels of L.G. Gibbon (pseudonym for J. Leslie Mitchell) and Arthur Koestler, published in 1933 and 1939 respectively. Gibbon presents a clearly socio-critical, romanticizing version of Spartacus, while Koestler, the "renegade" of Communism, describes the slave revolt as an example of a revolution that, like all revolutions, is doomed to failure. Just as Koestler, (The Gladiators, 316-319), observes in his "Postscript to the Danube Edition of 'The Gladiators,' " he began writing his novel at the time of the Stalinist purges around 1935, when he was still a member of the party, but already experiencing "progressive disillusionment with the Communist Party"; for him the novel became a "story of another revolution that had gone wrong": "Spartacus was a victim of the 'law of detours,' which compels the leader on the road to Utopia to be 'ruthless for the sake of pity.' " Koestler understood The Gladiators as the counterpart to his novel Darkness at Noon (1941), the story of the Bolshevik commissar Rubashov, who pursued this "law of detours" to its bitter end, only to realise that his ideas had failed: "Thus the two novels complement each other - both roads end in a tragic cul-de-sac."

23 After the Italian Ulisse, he starred in Vincente Minelli's Lust for Life (1956) and Richard Fleischer's The Vikings (1958).

24 Kirk Douglas, The Ragman's Son: An Autobiography (New York: Simon and Schuster, 1988) 303-305.

\section{(c) 2013 Koninklijke Brill NV ISBN 978-90-04-18320-9}


in Egypt, at the palaces in India, I wince. I see thousands and thousands of slaves carrying rocks, beaten, starved, crushed, dying. I identify with them. As it says in the Torah: 'Slaves were we unto Egypt.' I come from a race of slaves. That would have been my family, me.

This "humanist" enthusiasm, set against a religious Jewish background, attests to quite a different reading of Fast's novel than one colored by communism or the class struggle - and this might have been related to the fact that Douglas, whose own production company, Bryna Productions, took charge of making arrangements for the film, commissioned Dalton Trumbo rather than Fast to write the script. In doing so, Douglas nevertheless took a clear political decision: both Fast and Trumbo were among those blacklisted during the 1950s and hence banned from practicing their professions during the anticommunist persecutions raging at the time. After a decade of McCarthyism, Spartacus was the first film to defy the ban of persecuted authors and to mention their names officially in the credits. ${ }^{25}$

Trumbo in his script seems to have softened somewhat the differentiation between the Romans and slaves but nevertheless gives considerable weight to the military victories carried off by the slave army. Stanley Kubrick, however, did not appear to share this view. ${ }^{26}$ On the one hand, some of Kubrick's statements reveal his endeavor to convey historical authenticity or perhaps more precisely to visualize a foreign world. ${ }^{27} \mathrm{On}$ the other, he was less interested in idealizing the slaves as a harmonious collective than in depicting the tensions among the characters, which accounts for his intention to integrate elements from Koestler's The

25 See Futrell, "Seeing Red. Spartacus as Domestic Economist," 97-99; Maria Wyke, Projecting the Past: Ancient Rome, Cinema, and History (New York: Routledge, 1997) 60-63; Natalie Zemon Davis, Slaves on Screen. Film and Historical Vision (Cambridge, MA: Harvard University Press, 2000) 21-22; Theresa Urbainczyk, Spartacus (London: Bristol Classical Press, 2004) 119-125. One side-effect of this employment ban was the savings effect for production companies: blacklisted scriptwriters were still hired (albeit under ever different pseudonyms), but according to Urbainczyk (122) - unfortunately, her claim cannot be verified, since just as in other cases she provides no references - they received only a fraction of the previous fees. Urbainczyk points out that Trumbo could command up to $\$ 75,000$ before he was blacklisted, and was thereafter offered $\$ 3,750$. Bryna productions explained the fact that the company employed five blacklisted authors in 1959 by referring to its endeavor to keep costs low.

26 Douglas, who had played one of the lead roles in Kubrick's anti-war film Paths of Glory, dismissed Anthony Mann, who had been appointed by co-producer Universal International Pictures, after a few days of shooting. See Marcus Junkelmann, Hollywoods Traum von Rom. "Gladiator" und die Tradition des Monumentalfilms (Mainz: P. von Zabern, 2004) 392, fn. 467.

27 Davis, Slaves on Screen, 24-25.

\section{(C) 2013 Koninklijke Brill NV ISBN 978-90-04-18320-9}


Gladiators. ${ }^{28}$ Such widely differing views of the hero led to heated debates during the film's production, among others over the absence of victories by the slave army, the depiction of brutal or somewhat fairly aestheticized battle scenes, the all-too Christological demise of Spartacus on the cross, and the restriction of hope for liberation to one son. ${ }^{29}$ The result was a work with which nobody apart from Kirk Douglas as its producer and leading actor was truly satisfied; it nevertheless became the greatest box office success of $1960 .{ }^{30}$ Perhaps this success was indebted precisely to the broad spectrum of meanings and emotions into which entered the various strands of Spartacus' body fiction: a modern, popular hero carrying ancient references. The body of Kirk Douglas, the "steely-eyed and virile star,"31 superimposed itself on a symbolic body created over the past two hundred and fifty years. Consequently, Douglas' body became part of the evolving body fiction and a model for future transformations (see Figure 2).

The films made from the 1950s through the mid-196os reveal the sociocultural dimension of Spartacus as a heroic figure. Notwithstanding their dramaturgical concessions to the narrative conventions of the cinema as an institution, ${ }^{32}$ Freda's and Kubrick's films, released in 1953 and 1960

28 Duncan L. Cooper, "Dalton Trumbo vs Stanley Kubrick: The Historical Meaning of Spartacus," in Winkler, Spartacus, 58-60.

29 For a detailed discussion, see Ibid. and Duncan L. Cooper, "Who Killed the Legend of Spartacus? Production, Censorship, and Reconstruction of Stanley Kubrick's Epic Film," in Winkler, Spartacus, 14-55. Both accounts read like a written defense of Dalton Trumbo and at the same time constitute a plea for the restauration of the film with material partly shot later, but which was subsequently not included in the final version. Cooper had already published earlier versions of these texts, which trace the conflicts in detail, namely, in Cinéaste and an electronic version in 1996 at http://www.visual-memory.co.uk/amk/doc/ cooperdex.html (accessed on February 16, 2012). Junkelmann, Hollywoods Traum von Rom, 151-158, also assembles anecdotal material on the differences of opinion between director, scriptwriter, novelist, and actors; on the other hand, however, his description reveals a lack of understanding for the historical film as a genre and of the cinema as an institution; see, for instance, his comment $(156)$ that "like in so many historical films, the grafted love story has a highly detrimental effect."

30 Martin M. Winkler, "The Holy Cause of Freedom: American Ideals in Spartacus," in Winkler, Spartacus, 168, explains the failure of the conservative propaganda against the film by the fact that it was ultimately "a mainstream American work," which presents an "all-American Spartacus." Winkler also attempts to describe in some "key scenes" how the film corresponds to the American zeitgeist and the prevailing discourses in the early $1960 s$.

31 Thus begins the minibiography of Kirk Douglas available online at http://imdb.com/ name/nmooooo18/ (accessed on February 16, 2012).

32 See, for instance, Robert A. Rosenstone, "History in Images/History in Words: Reflections on the Possiblity of Really Putting History Into Film," American Historical Review 93 (1988) 1173-1185; see also Philip Rosen, Change Mummified. Cinema, Historicity, Theory

(C) 2013 Koninklijke Brill NV ISBN 978-90-04-18320-9 


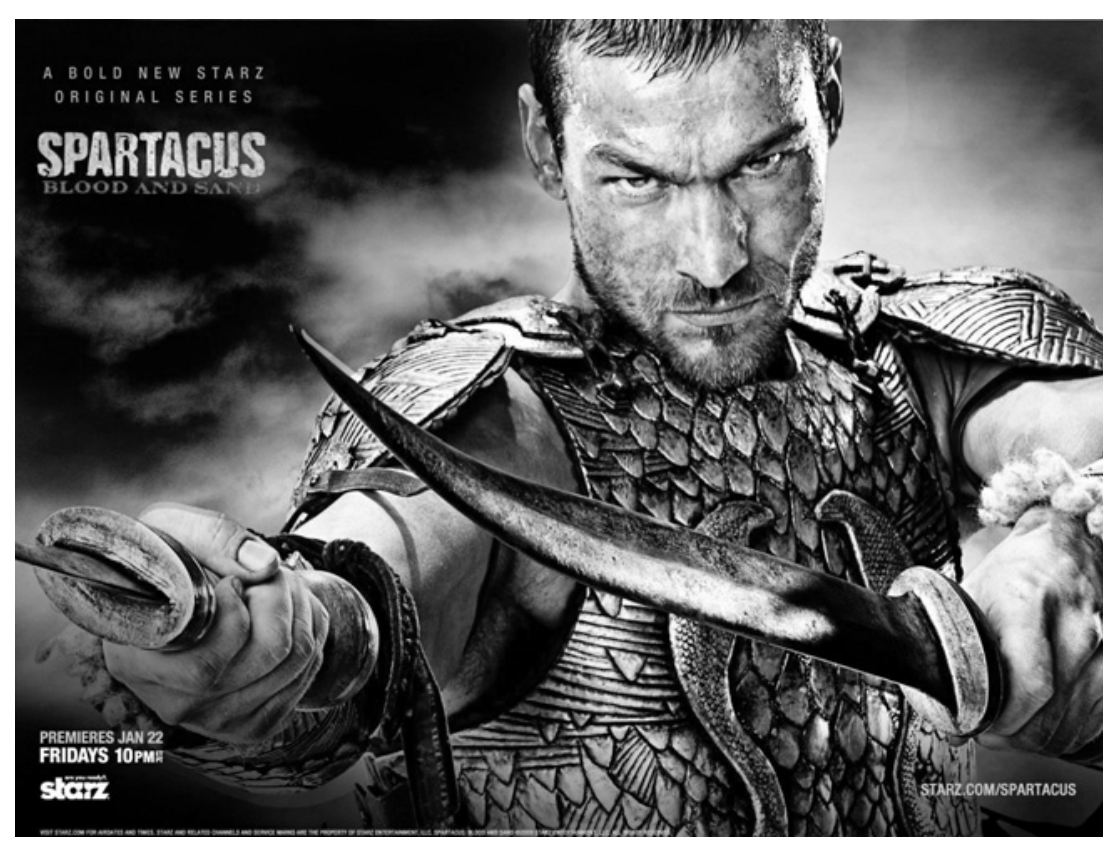

Figure 2 Andy Whitfield as Spartacus in the TV-Series Blood and Sand by Steven S. DeKnight (2010)

respectively, can be said to have at least laid claim to historical reference, thereby placing themselves within the tradition of the image of Spartacus that had evolved since the eighteenth century. Besides these two cinematic versions, at least three other Italian productions were made during this period, each treating the leader of the slave rebellion in a fictionalizing, fantastic manner: Il figlio di Spartaco (1963), directed by Sergio Corbucci; Spartaco e i dieci gladiatori (1964; a.k.a. Gli invincibili dieci Gladiatori), directed by Nick Nostro; and La vendetta di Spartacus (1965), directed by Michele Lupo. ${ }^{33}$

(Minneapolis: University of Minnesota Press, 2001) 147-199, esp. 178-180; Davis, Slaves on Screen, $1-15$.

33 The renaissance of films set in classical antiquity since Gladiator (2000) has recently led to the aforementioned television series directed by Robert Dornhelm (Spartacus, 2004) and by Steven S. DeKnight (Spartacus: Blood and Sand, 2010), and furthermore to two so-called documentaries on Spartacus (The Real Spartacus, Bill Lyons, 2001); Espartaco Informe confidential, Jorge Ortiz de Landázuri Yzarduy, 2003), and one short (Spartacus, Virginie Lovisone, 2003); in the wake of this development, a new DVD edition of Il colosso di Roma/Muzio scevola (Giorgio Ferroni, 1964) was launched without further ado under the German title Spartacus - Der Held mit der eisernen Faust, although the film's protagonist is Gaius Mucius Scaevola ("the left-hander"), the legendary Roman hero (see Livy 2.12.1-13.5).

(C) 2013 Koninklijke Brill NV ISBN 978-90-04-18320-9 
Corbucci's film invents the continuation of the "story" in the adventures of Spartacus' son. Unaware of his true identity, Randus is taken prisoner by slave traders while serving as one of Caesar's (Roman) officers in Egypt. When he finds out about his true origin, he declares that "If Rome is for slavery, then I'm against Rome." Henceforth, he resumes the struggle against slavery. Eventually, however, he reestablishes Caesar's good rule, which protects the people against the barbaric tribal leaders, the "Saracens," as much as against the corrupt Roman governors. Or as Richard Dyer has aptly observed: "[He] restores enlightened colonialism." 34 Randus, Spartacus' son, is played by bodybuilder Steve Reeves, who portrays him as a very southern type in an exotic, oriental setting, whose cinematic desert iconography, like its representation of violence in the fighting scenes, already seems to anticipate the Italian Western. ${ }^{35}$ The two other films inherit from the figure of Spartacus the idea of the slave revolt. However, this serves only to initiate the staging of a sequence of loosely connected wrestling and battle scenes as well as feasts, the excess of which also parodies the genre of films set in classical antiquity. This development places the figure of Spartacus within a series of mythified fantasy figures, of musclemen like Ursus, Hercules, Samson, or Maciste: ${ }^{36}$ the popular hero as it were returns to vaudeville theater, where the physical and cinematographic spectacle attracts greater attention than the level of values and emotions inherited from the bourgeois theater of the Enlightenment (Bernard-Joseph Saurin's tragedy, Spartacus, 1760) and from the nationalist and socio-critical novel (Giovagnoli, Fast).

34 Richard Dyer, White (London: Routledge, 1997) 176.

35 See also Il Figlio di Cleopatra (1962), directed by Ferdinando Baldi, where the physical appearance and body display of the bodybuilder Mark Damon, who appears in the role of El Kabir, is made to resemble that of a bedouin, and is thus even more strongly "orientalized" and erotized. On the orientalization of white musclemen, see Dyer, ibid., 177; for a discussion of the eroticizing and feminizing of male and female figures as an Oriental Other, see Ella Shohat, "Gender and Culture of Empire: Toward a Feminist Ethnography of the Cinema," in Hamid Naficy, Teshome H. Gabriel, eds., Otherness and the Media. The Ethnography of the Imagined and the Imaged (Langhorne, PA: Harwood Academic Publishers, 1993) $45^{-84}$.

36 See Vittorio Martinelli's extensive "filmography" of Italian productions in the period from 1913 to 1926 in Monica dall'Asta, Un cinéma musclé: le surhomme dans le cinéma muet italien (1913-1926) (Crisnée: Yellow Now, 1992) 215-253. See also Monica dall'Asta, "Maciste - ein Stereotyp westlicher Männlichkeit," KINtop 7 (1998) 84-97. Annie Collognat, "L'antiquité au cinéma," Bull. Ass. G. Budé (1994-95) 334-336, claims that fifteen Maciste films were produced between 1915 and 1920, and she refers to six Maciste productions between 1961 and 1963 . 
The figure of Spartacus, bearing nothing more of classical antiquity than his name, is very well-suited to delineate the complexity of the peplum heroes of the 1950s through mid-196os, and their ability to be modulated, and to recognize them as a historical and fictional conglomerate that somehow remained valid both before and after this period. Indeed, Spartacus proves to be a highly alterable body hero, a vehicle onto which the historical and the contemporary can load ever new associations. The figure can lift and carry the political, social, moral, economic, and even cinematographic concerns into the different instances of actualization, where they come to rest, accumulate, and amalgamate (in Paul Ricoeur's sense of the transhistorical self-structuring "sedimentation" of tradition, or as a "collage of commonplaces" in Gramscian terms). ${ }^{37}$ Our current cinephile memory is certainly dominated by the image of Kirk Douglas as Spartacus. ${ }^{38}$ We can nevertheless assume that at least the Spartacus films made between 1953 and 1965 respond to one another, and that they plausibly blend into a multifaceted image in contemporary reception (which lasted well into the 1970s through their international release on television and in rural cinemas). ${ }^{39}$ Even if the figure of Spartacus might not necessarily stand out from the mass of sword and sandal films of that time for the average spectator, we argue that it nevertheless serves analysis as an example. Spartacus can be considered a popular hero insofar as Freda's and especially Kubrick's films were commercial successes as well as political and media events.

37 See Paul Ricoeur, Temps et récit (Paris: Seuil, 1984) II, 30-31, on the notion of the cumulative tradition, whose process-like nature we transfer here onto historical figures in films set in classical antiquity as a configuration of cultural memory. In describing the conception of history in biopics, Marcia Landy draws on Gramsci's notion of folklore as a palimpsest; see Marcia Landy, Cinematic Uses of the Past (Minneapolis: University of Minnesota Press, 1996) 151-161. Both concepts are similar to the aforementioned idea of the appropriation of history in the "dialectical image," as conceived by Benjamin, "Über den Begriff der Geschichte," who also understood this as a mnemonic image.

38 See here the comments collected at http://imdb.com/title/tto361240/usercomments (accessed on February 16, 2012) regarding the reedition of Dornhelm's "myth" of Spartacus in 2004; most commentators mostly compare Goran Visnjic and the film with the 1960 original.

39 On the current intertextuality of films set in classical antiquity, see Michèle Lagny, "Dans les pas d'Achille et d'Alexandre," in Lochman, Späth, and Stähli, Antike im Kino, 202-209. Winkler's assertion in his "Introduction" (Winkler, Spartacus, 8), namely, that Kubrick's Spartacus "has eclipsed all other Spartacus films made before or after," is thus certainly too simple.

\section{(C) 2013 Koninklijke Brill NV ISBN 978-90-04-18320-9}




\section{Body Fictions of Masculinity}

Three interlocking levels enter into the imaginary body fiction of the cinematic Spartacus. These three levels actualize with different weight in the various cinematic versions the triform heroic figure mentioned above, and thus often are contradictory in themselves. While these aspects need not necessarily belong to the body fiction of a historical figure, films set in classical antiquity include the staging of the muscular body. The following levels can thus be distinguished: archaic masculinity, the conglomerate of values of the domesticated superhero, and the body as a media spectacle.

\section{Archaic Masculinity}

Archaic masculinity refers back to the strongmen appearing at fairgrounds, in vaudeville theater, and in early cinema. It has stood behind the figure of Spartacus at least since Edwin Forrest's initial 1831 performance in Robert Bird's The Gladiator. ${ }^{40}$ Such masculinity is about the demonstration of physical strength:41 the fighting men are presented more or less as human beings possessing above-average strength and courage. Gladiators and slaves are thereby repeatedly associated with animal elements: they fight against animals or like animals, or they are treated like animals, wear animal skins, or are only scantily clad. ${ }^{42}$ For the Romans, they have not yet

40 Robert Montgomery Bird, “The Gladiator," in Jeffrey H. Richards, ed., Early American Drama (New York: Pengin Books, 1997).

41 Charles-Antoine Courcoux, "From Here to Antiquity: Mythical Settings and Modern Sufferings in Contemporary Hollywood's Historical Epics," Film \& History 39 (2009) 29-38, shows the connection between masculinity and nature in recent Hollywood productions set in antiquity. On the staging of archaic masculinity in early cinema, which stems from nineteenth-century fairground traditions, see dall'Asta, Un cinéma musclé. Irmbert Schenk, "Von Cabiria zu Mussolini. Zur Geburt des monumentalen Historienfilms in Italien," in Malte Hagener, Johann N. Schmidt, and Michael Wedel, ed., Die Spur durch den Spiegel. Der Film in der Kultur der Moderne (Berlin: Bertz, 2004) 180, also mentions a connection between early films set in classical antiquity and opera; he also discusses (182) the interrelation between the birth of the monumental historical film in Italy and the fascist "fantasies of collective greatness." On the fascist iconography of musclemen, see also, Dyer, White, $169-174$.

42 Not only the slaves but also the enemy soldiers - the gangs under Crassus' command appearing in Corbucci's Il Figlio di Spartaco wear leopard skins, similarly to Baldi's Il Figlio di Cleopatra. Other films portray the Germanic peoples (barbarians) as feral humans or half animals, such as Sergio Grieco's Antea, la schiava di Roma (1960). Wearing animal skins is a sign of the barbaric in films set in classical antiquity; Natacha Aubert, "Roger Moore en Romulus: Tite-Live lu par Cinecittà (L'Enlèvement des Sabines, Richard Pottier, 1961)," in Lochman, Späth, and Stähli, Antike im Kino, 194-201, has shown that the early Romans were also presented thus in Richard Pottier's The Rape of the Sabines (1960).

(C) 2013 Koninklijke Brill NV ISBN 978-90-04-18320-9 
entered civilization, as reflected in their darker complexion, which marks them as culturally other and socially inferior. ${ }^{43}$ Where the cinema endows slaves with the power of conviction to rise against (Roman) oppression and decadence, they represent what Joseph Campbell called the "primordial hero." Such a hero accomplishes or will accomplish the superhuman, and will thus "create a world," 44 as if making a cinematic promise to history to abolish slavery, or present-day injustice and poverty. While slave revolts usually begin impulsively, spontaneously, and chaotically, ${ }^{45}$ within the cinematic production code such action legitimates and ennobles the use and representation of violence, and thus archaic masculinity, in the service of humanity and "natural law." At the same time, however, the rebellious slaves must also learn to control their physical strength and passions and to gain access to language (that is, the symbolic): Kubrick's Spartacus in particular explicitly foregrounds this theme by having Spartacus exemplify this development. 46

43 Dyer, White, 161-162. Besides the ethnic and social aspects of class, the gradation of complexions by gender also becomes fundamental: male characters tend to have darker skin than female ones (or are shot in corresponding light), as in the aforementioned Spartacus films. Tomas Lochmann has drawn our attention to the fact that comparable markings also occur in the iconography of Attic vase painting.

44 Joseph Cambell, The Hero With a Thousand Faces (Novato, CA: New World Library, 2008) 271-278.

45 Precisely this aspect singles out Kubrick's Spartacus for the ideologically underpinned criticism leveled at the film in the East German program text (Heinz Hofmann, "Spartacus," Progress Film Programm 50, 1966 [four-page foldout]): “As a master swordsman, Spartacus had organized a plot in the gladiator school at Capua and was able to escape with his supporters. But the film distorts this into a spontaneous act.... Different versions concerning the goal of the uprising, conditioned by social groupings which harbored self-serving plans, led to several splits among the slave army, which became weaker and weaker. Even these essential historical facts of the case are suppressed in the film, whereas Rome concentrated all its power on its defeat."

46 Ina Rae Hark, "Animals or Romans. Looking at Masculinity in Spartacus," in Hark and Steven Cohan, eds., Screening the Male. Exploring Masculinities in Hollywood Cinema (London: Routledge, 1993) 151-172, illustrates the development from the animal to the human and to language in Kubrick's Spartacus. The Christological association, present in both Kubrick and Freda, also extends this connection to the biblical film set in classical antiquity. As Ashton D. Trice and Samuel A. Holland, in Heroes, Antiheroes and Dolts: Portrayals of Masculinity in American Popular Films, 1921-1999 (Jefferson, NC: McFarland, 2001) 97, emphasize, this stages the development of the hero from heathen to Christian, from "sinner" to "saint." Such changes, especially with regard to the protagonist, can be interpreted as a basic "civilizing" instance of purification and of the knowledge (of becoming human and undergoing acculturation), which also occurs in a different form in the bourgeois Bildungsroman.

\section{(C) 2013 Koninklijke Brill NV ISBN 978-90-04-18320-9}




\section{The Domesticated Superhero}

This "becoming human" leads us to the second level, that of heroic values: where the "primordial hero" possesses at best a Manichaean morality, as Maciste already does in Giovanni Pastrone's Cabiria (1914), and which serves to save the weak, the idolized woman, and civilization (that is, humanity), ${ }^{47}$ in following the example of Spartacus the slaves acquire considered action, military and political tactics, class consciousness, solidarity and the passion of the heart for the beloved woman, as well as a sense of family. These aspects charge the genre of the war film with moral, ethic, ideological-political, melodramatic, and, in the case of the Bible film, also with explicitly Christian components. Spartacus, the superhero (who is "larger than life") unites all these aspects in himself, apart from the openly Christian one, as long as he remains bound to the axiological role pattern as in Freda, Kubrick, and Corbucci. However, he is not superhuman but instead has doubts, feels the burden of responsibility, is vulnerable to feelings, and is overwhelmed by the historical situation. ${ }^{48}$ Even if his death turns him into a martyr and preserves the historical-mythical image of the hero, his narrative representation (regardless of the version) turns him into a bourgeois-tragic hero: when actualized in the 1950s, the hero has internalized the conflict and must subject his whole life to the demands of his convictions. ${ }^{49}$

Spartacus thus approaches the vanquished and the broken anti-heroes of other contemporary genres, which stage the crises of masculinity, the self-made man, and social values. He thereby never becomes a truly individual, psychological character, nor does he ever allow himself to be entirely domesticated. Rather, the ideas for which he fights "transcend" him, ${ }^{50}$ even if - similarly to an anti-war film - his concrete moral and political ideals for humanity are (temporarily) lost. In the popular genre

47 dall'Asta, Un cinéma musclé, 41, refers to Umberto Eco, who establishes the figure of the Maciste and its narrative patterns as a new phenomenon of the nineteenth-century popular novel. She describes this "strongman" as an "incomplete subject" (45).

48 Francis Vanoye, Scénarios modèles, modèles de scenarios (Paris: Nathan, 1991) 53-54, thus describes the modern "problematic character."

49 See Peter Szondi, Die Theorie des bürgerlichen Trauerspiels im 18. Jahrhundert: der Kaufmann, der Hausvater und der Hofmeister (Frankfurt am Main: Suhrkamp, 1973) $84-85$.

50 As in Freda, where the hero's melodramatic inclination to passionate, impossible love for Sabina leads his values into disarray, it is realigned by his mission: when the screaming of a tortured slave reawakens his class consciousness after an amorous adventure with Sabina, he tears open his tunic before returning to his own kind and once again bares his chest (the "animal" moment seems well-suited to the tragic hero here).

(C) 2013 Koninklijke Brill NV ISBN 978-90-04-18320-9 
of the peplum, however, no coherent, unified discourse emerges beyond the general humanist message of peace, freedom, and justice. Within his specific character constellation, the ancient collective hero (as a body fiction), who fights for a better society and fails, can thus voice specific contemporary concerns. For example, Kubrick's Spartacus echoes those of the McCarthy era, the civil rights movement, feminism, and homosexuality, while he also conveys the bourgeois, middle class values of the nuclear family, muscular manhood, cool restraint, and intelligence. Through its contradictoriness and "openness," such a cinematic work of popular culture can be appropriated by different sides, ${ }^{51}$ just as this seems to have contributed to making it (and to a certain extent also films set in classical antiquity in general) an outstanding success. ${ }^{52}$

\section{The Body as a Media Spectacle}

Physical performance and the staged representation of the body in the media turns the hero into a star especially on a third level. The studios endorsed the motto "Bigger is Better" to respond to the crisis of the cinema in the face of growing competition from television in the United States and to stimulate coproductions. ${ }^{53}$ Internationally distributed monumental films produced in Hollywood and Cinecittà, which was rebuilt after the war largely with the help of American money, demonstrate economic power, state-of-the-art technology, and are structured like media events, as Vivian Sobchack has observed. ${ }^{54}$ Not only actresses but also male bodies are touted for their beauty and erotic charisma. However, the

51 On the theory of popular culture as a many-layered and often contradictory range of available meanings, see, among others, Umberto Eco, "Die Struktur des schlechten Geschmacks," in Eco, Apokalyptiker und Integrierte. Zur kritischen Kritik der Massenkultur (Frankfurt am Main: S. Fischer, 1984) 59-115, and John Fiske, "Popular Culture," in Frank Lentricchia and Thomas McLaughlin, eds., Critical Terms for Literary Study (Chicago: University of Chicago Press, 1990) 321-335; on the problems of the notion of popular from the point of view of reception, see Pierre Sorlin, "Les deux périodes antiquisantes du cinéma italien," in Lochman, Späth, and Stähli, Antike im Kino, 88-97.

52 President John F. Kennedy also took a public stand against anti-communist and Catholic calls to boycott the film; see Wyke, Projecting the Past, 71, fn. 123 and 200, and Winkler, Spartacus, 188, fn. 60.

53 Trice and Holland, Heroes, Antiheroes and Dolts, 96.

54 Vivian C. Sobchack, "Surge and Spendor. A Phenomenology of the Hollywood Historical Epic," Representations 29 (1990) 24-49. On the monumental film as the eternal recurrence of the same, see Klaus Kreimeier, "Der mortifizierende Blick: Von der Wiederkehr des Immergleichen im Monumentalfilm," in Jürgen Felix, Bernd Kiefer, Susanne Marschall, and Marcus Stiglegger, eds., Die Wiederholung (Marburg: Schüren, 2001) 325-334.

(C) 2013 Koninklijke Brill NV ISBN 978-90-04-18320-9 
review of Vidali's Spartaco of 1913, published at the time in the Hungarian German-speaking newspaper Neues Pester Journal, reveals that such advertising is by no means a new phenomenon. It was already a feature of the cinema industry during the large-scale productions of the 1910s. The reviewer praises Maria Guaita's athletic body as the "epitome of human beauty!"; Guaita had won the male beauty prize awarded by the Académie des Beaux-Arts de Paris for his "classical features" and his "unsurpassable physique (according to the magazine Pesti Kirlap). ${ }^{55}$ Vidali's film was also praised for its crowd scenes and atmospheric set design. ${ }^{56}$ Writing about Fred Niblo's Ben Hur (1925) as a "lavish opera," Siegfried Kracauer also mentions in the same breath the cost of materials, the crowds, and the physical appearance of Ramon Novarro, who "is as beautiful as Valentino," and epitomizes "the American-Spanish-Mexican type." He thus underscores the internationality of the film. ${ }^{57}$

What is new in the 1950s is at best the fact that widescreen cinemas, technicolor processes, sophisticated technical effects, and larger budgets permitted even more magnificient stagings of the battle of materials. ${ }^{58}$ The cinema as spectacle and the spectacle of the oiled, gleaming, raw, muscular bodies of half-naked male protagonists, who were often played by bodybuilders, models, or sportsmen already in the limelight beyond the cinema, and whose monumental performances complemented or surpassed each other, also explicitly addressed the contemporary female audience. ${ }^{59}$ Obviously, male bodies are thereby commodified: they are often staged as erotic, exotic-oriental objects of desire mostly exaggerating the southern type to appeal to the female protagonists and audience. ${ }^{60}$ Their visible

55 Both articles are quoted by Martinelli in dall'Asta, Un cinéma musclé, 216.

56 See the contemporary critique by James McQuade in Moving Picture World (quoted in Davide Turconi, "I film storici italiani e la critica americana dal 1910 alla fine del muto," Bianco e Nero 24 (1963) 52-56.

57 Siegfried Kracauer, "Ben Hur," in Karsten Witte, ed., Kino: Essays, Studien, Glossen zum Film (Frankfurt am Main: Suhrkamp, 1974) 163-165.

58 Cabiria (1913) exhibits not only lavish material costs but also the (childlike) joy in destruction, in a "battle of materials," since the pompous decor of the villa situated at the foot of Mount Vesuvius has been leveled to the ground within ten minutes of the film's opening. The monumental films produced in the 1950s enhance this demonstration of materials and large dimensions, which Sobchack, "Surge and Spendor: 29, interprets as an expression of flourishing capitalism, in whose excess we participate as "embodied spectators" and "historical subjects." It is worth recalling that the Guiness Book of Records was also first published in 1955 .

59 Trice and Holland, Heroes, Antiheroes and Dolts, 99, mention the advertising for DeMille's Samson and Delilah (1949), which explicitly addressed the female audience; the film review published in New York Times touted the leading actor Victor Mature as a "hunk" (that is, 'an attractive and well-built man').

60 See Dyer, White, $147-155$, and 167.

\section{(C) 2013 Koninklijke Brill NV ISBN 978-90-04-18320-9}


and unfettered physicality and performance confers upon the artificiality of the monumental film a physical authenticity. At the same time, the archaic masculinity of the primordial hero is aestheticized by the mediabased and economic-technical demonstration of performance, and thus consoles us for the uncertainty of values or, in the case of those films only featuring wrestling scenes, for their absence. ${ }^{61}$ Reminiscent of the excess of Baroque churches and its overwhelming effects, going to the cinema becomes an event and experience that attempts to produce "the highest degree of immediate physical existence both on the screen and also for the audience." ${ }^{2} 2$ Such an event and experience enables the cinematic and physical spectacle to somehow reclaim the moral hero. ${ }^{63}$

\section{Setting Free Morality}

The following remarks are couched in general terms because the Spartacus films are no exception in this respect: whether auteur cinema or B-movie, they always stage the muscular male hero - more or less aesthetized, eroticized, and endowed with moral values - for the media and physical experience of the monumental. The body fiction of the spectacle and of the (capitalist) machinery of the cinema surpasses the historical figure by far. If history is an "intoxicant," as Peter von Matt has remarked with reference to historical narratives, ${ }^{64}$ then the films set in classical antiquity produced during the economic miracle of the 1950s and 1960s, in whose surge they allowed spectators to participate, reactualize the enchantment

61 If the female characters appearing in the various Spartacus films (Freda, Kubrick, Corbucci, Dornhelm) also join the male protagonists in their struggle for moral-humanist values, Spartacus "outdoes" their media performance (in combination with archaic masculinity); beyond the individual body, the choreography of these films emphasizes the staging of masculinity. Gender differences are thus affirmed on another level. Yet, following Heide Schlüpmann, "Die Geburt des Kinos aus dem Geist des Lachens," Frauen und Film 53 (1992) 87-94, it could be argued that the physical spectacle makes possible a new physical and sensual relationship between the sexes, even in parodistic wrestling films, which tend to be misogynistic.

62 Siegfried Kracauer, "Geschichte und Fantasie," in Theorie des Films: Die Errettung der äußeren Wirklichkeit (Frankfurt am Main: Suhrkamp, 1984) 119, with reference to Niblo's Ben Hur. His sense of realism coincides here with Vivian Sobchack's phenomenological approach.

63 The popular films set in classical antiquity produced in the 1950s and 196os already anticipate the "new" superhero of action films made in the 1980s; see Trice and Samuel A. Holland, Heroes, Antiheroes and Dolts, 96-98, or Yvonne Tasker, Spectacular Bodies: Gender, Genre and the Action Cinema (London: Routledge, 1993).

64 See Von Matt in the introduction to Die tintenblauen Eidgenossen (2001), quoted in Sibylle Birrer, "Neues vom Alten. Historische Romane und ihre anhaltende Popularität," Neue Zürcher Zeitung 26 (2002) 59.

\section{(C) 2013 Koninklijke Brill NV ISBN 978-90-04-18320-9}


of the world, ${ }^{65}$ which has always been inherent in the cinema. Functioning as intoxicants, such films combat the overlapping crises of the cinema, of morality, and of masculinity.

The "morality" of these films has at least two (paradoxical) meanings: an ousting of morality in favor of the monumental and excessively physical spectacle; and a setting free of moral, sometimes political, but especially generally humanistic categories, which offer a manifold parallel range of meanings that legitimates excess but also puts it in its place once again.

\section{The Body Fiction of Ancient Figures}

Returning to our initial hypothesis, we can now formulate three claims arising from our overview of the construction and permanent modification of Spartacus as a body fiction. First, Comolli's concept of the corps en trop must be reformulated for films set in classical antiquity, since the body fiction of ancient figures in general and that of Spartacus in particular can hardly be based on a popularly transmitted iconography, nor can historical knowledge produce a truly concrete notion that would interfere with the actor's embodiment of the figure. His name evokes the symbolic body as a malleable shell. The ancient figure possesses no continuous body image, which is instead created through the actualizations of classical antiquity since the Renaissance or, in the case of Spartacus, since the Enlightenment, even if constants can be discerned at times. Especially in the scenic and subsequent cinematic actualizations of the ancient figure by different actors, their mediated physicality becomes foregrounded; in certain cases, the image of the actress or actor dominates the body fiction for a certain time.

Second, this also means that antiquity exists largely in the popular imaginary as a fictional construct, which serves as a point of reference that confers upon the material and the historical figures a sense of authenticity. For these films, however, antiquity is myth, whether in Bondanella's terms or those of classical Greek tragedy. It is raw material, available for almost any shaping and adjustment.

Third, the historical-sensual body of ancient figures is created predominantly within a body of interrelated films. Early cinema, however, takes

65 As a countermove to the "disenchantment of the world" by science in modern society, as described by Max Weber, "Die Entzauberung der Welt," in Weber, Wissenschaft als Beruf (Stuttgart: Reclam, 1995) 44.

(C) 2013 Koninklijke Brill NV ISBN 978-90-04-18320-9 
up the popular iconography of nineteenth-century (muscular) bodies, and at the same time graces itself with the cultural, bourgeois value of ancient themes and, in the case of the story of Spartacus, with its variable appropriation and semantic flexibility since the Enlightenment. The emotional diversity of meanings carried by an ancient figure thus emerges over time, especially in the conversation among individual films. This process of accumulating figural aspects, and with them the conglomerate of facets that transform the symbolic body time and again, continues to elaborate the popular notion of ancient history. ${ }^{66}$

\section{Works Cited}

Aubert, Natacha. "Roger Moore en Romulus: Tite-Live lu par Cinecittà (L'Enlèvement des Sabines, Richard Pottier, 1961)," in Tomas Lochman, Thomas Späth, and Adrian Stähli, eds., Antike im Kino: auf dem Weg zu einer Kulturgeschichte des Antikenfilm (Basel: Verlag der Skulpturhalle Basel, 2008) 194-201.

Belting, Hans. Bild-Anthropologie. Entwürfe für eine Bildwissenschaft (Munich: W. Fink, 2001).

Benjamin, Walter. "Über den Begriff der Geschichte," in Siegfried Unseld, ed., Illuminationen. Ausgewählte Schriften (Frankfurt am Main: Suhrkamp, 1977) 251-263.

Bird, Robert Montgomery. "The Gladiator," in Jeffrey H. Richards (ed.), Early American Drama (New York: Pengin Books, 1997).

Birrer, Sibylle. "Neues vom Alten. Historische Romane und ihre anhaltende Popularität," Neue Zürcher Zeitung 26.2 (2002) 59.

Bondanella, Peter. The Eternal City: Roman Images in the Modern World (Chapel Hill and London: University of North Carolina Press, 1987).

Bradley, Keith. Slavery and Rebellion in the Roman World, 140 B.C.-7o B.C. (Bloomington: Indiana University Press, 1989).

Cambell, Joseph. The Hero With a Thousand Faces (Novato, CA: New World Library, 2008).

Collognat, Annie. "L’antiquité au cinéma," Bull. Ass. G. Budé (1994-95) 332-351.

Comolli, Jean-Louis. "La fiction historique: un corps en trop," Cahiers du cinéma 278 (1977) 5-16 [= "Historical Fiction: A Body too much," Screen 19 (1978) 41-53].

Cooper, Duncan L. "Who Killed the Legend of Spartacus? Production, Censorship, and Reconstruction of Stanley Kubrick's Epic Film,” in Martin Winkler, ed., Spartacus: Film and History (Malden, MA; Blackwell, 2007) 14-55.

—. "Dalton Trumbo vs Stanley Kubrick: The Historical Meaning of Spartacus," in Winkler, Spartacus: Film and History, 56-64.

Coudry Marianne, and Thomas Späth, eds., L'invention des grands hommes de la Rome antique. Die Konstruktion der grossen Männer Altroms. Actes du colloque du Collegium Beatus Rhenanus (Paris: Collections de l'Université Marc Bloch - Études d'archéologie et d'histoire ancienne, 2001).

Courcoux, Charles-Antoine. "From Here to Antiquity: Mythical Settings and Modern Sufferings in Contemporary Hollywood's Historical Epics," Film \& History 39 (2009) 29-38.

dall'Asta, Monica. Un cinéma musclé: le surhomme dans le cinéma muet italien (1913-1926) (Crisnée: Yellow Now, 1992).

66 We gratefully acknowledge Mark Kyburz for his translation.

(C) 2013 Koninklijke Brill NV ISBN 978-90-04-18320-9 
"Maciste - ein Stereotyp westlicher Männlichkeit," KINtop 7 (1998) 84-97.

Davis, Natalie Zemon. Slaves on Screen. Film and Historical Vision (Cambridge, MA: Harvard University Press, 2000).

Douglas, Kirk. The Ragman's Son: An Autobiography (New York: Simon and Schuster, 1988).

Dyer, Richard. White (London: Routledge, 1997).

Eco, Umberto. "Die Struktur des schlechten Geschmacks," in Eco, Apokalyptiker und Integrierte. Zur kritischen Kritik der Massenkultur (Frankfurt am Main: S. Fischer, 1984) 59-115.

Fast, Howard. Being Red (Boston: Houghton Mifflin, 1990). Spartacus (New York: n.p., 1951).

Fiske, John. "Popular Culture," in Frank Lentricchia and Thomas McLaughlin, eds., Critical Terms for Literary Study (Chicago: University of Chicago Press, 1990) 321-335.

Futrell, Alison. "Seeing Red. Spartacus as Domestic Economist," in Sandra R. Joshel, Margaret Malamud, and Donald T. McGuire, Jr., eds., Imperial Projections: Ancient Rome in Modern Popular Culture (Baltimore: The Johns Hopkins University Press, 2001) 77-118.

Gibbon, Lewis Grassic [J. Leslie Mitchell]. Spartacus (London: Jarrold, 1933).

Hardwick, Lorna. Reception Studies (Oxford: Published for the Classical Association, 2003) [=Greece \& Rome: New Surveys in the Classics No. 33].

Hark, Ina Rae. "Animals or Romans. Looking at Masculinity in Spartacus," in Ina Rae Hark and Steven Cohan, eds., Screening the Male. Exploring Masculinities in Hollywood Cinema (London: Routledge, 1993) 151-172.

Hofmann, Heinz. "Spartacus," Progress Film Programm 50, 1966 [four-page foldout].

Junkelmann, Marcus. Hollywoods Traum von Rom. "Gladiator" und die Tradition des Monumentalfilms (Mainz: P. von Zabern, 2004).

Kantorowicz, Ernst H. The King's Two Bodies. A Study in Mediaeval Political Theology (Princeton: Princeton University Press, 1957).

Koestler, Arthur. The Gladiators (trans. Edith Simon; London: J. Cape, 1939).

Kracauer, Siegfried. "Ben Hur," in Karsten Witte, ed., Kino: Essays, Studien, Glossen zum Film (Frankfurt am Main: Suhrkamp, 1974) 163-165.

__. "Geschichte und Fantasie," in Theorie des Films: Die Errettung der äusseren Wirklichkeit (Frankfurt am Main: Suhrkamp, 1984) 115-134.

Kreimeier, Klaus. "Der mortifizierende Blick: Von der Wiederkehr des Immergleichen im Monumentalfilm," in Jürgen Felix, Bernd Kiefer, Susanne Marschall, and Marcus Stiglegger, eds., Die Wiederholung (Marburg: Schüren, 2001) 325-334.

Lagny, Michèle. "Popular Taste: The Peplum," Richard Dyer and Ginette Vincendeau, eds., Popular European Cinema (London: Routledge, 1992) 163-180.

Landy, Marcia. Cinematic Uses of the Past (Minneapolis: University of Minnesota Press, 1996).

Lochman, Tomas, Thomas Späth, and Adrian Stähli, eds., Antike im Kino: auf dem Weg zu einer Kulturgeschichte des Antikenfilms (Basel: Verlag der Skulpturhalle Basel, 2008).

Renoir, Jean. Ecrits 1926-1971 (Paris: P. Belfond, 1974).

Ricoeur, Paul. Temps et récit (Paris: Seuil, 1984).

Rosen, Philip. Change Mummified. Cinema, Historicity, Theory (Minneapolis: University of Minnesota Press, 2001).

Rosenstone, Robert A. "History in Images/History in Words: Reflections on the Possibility of Really Putting History Into Film," American Historical Review 93 (1988) 1173-1185; reprinted in Robert A. Rosenstone, Visions of the Past. The Challenging of Film to Our Idea of History, Cambridge, MA: Harvard University Press, 1995) 19-44.

Schenk, Irmbert. "Von Cabiria zu Mussolini. Zur Geburt des monumentalen Historienfilms in Italien," in Malte Hagener, Johann N. Schmidt, and Michael Wedel, eds., Die Spur durch den Spiegel. Der Film in der Kultur der Moderne (Berlin: Bertz, 2004) 179-192.

Schlüpmann, Heide. "Die Geburt des Kinos aus dem Geist des Lachens," Frauen und Film 53 (1992) 87-94.

\section{(C) 2013 Koninklijke Brill NV ISBN 978-90-04-18320-9}


Schöttker, Detlev. "Benjamins Bilderwelten. Objekte, Theorien, Wirkungen," in idem (ed.), Schrift, Bilder, Denken. Walter Benjamin und die Künste (Frankfurt am Main and Berlin: Suhrkamp, 2004) 10-31.

Shaw, Brent D. Spartacus and the Slave Wars. A Brief History with Documents (Boston, MA: Bedford/St. Martin's, 2001).

Shohat, Ella. "Gender and Culture of Empire: Toward a Feminist Ethnography of the Cinema," in Hamid Naficy, Teshome H. Gabriel, eds., Otherness and the Media: The Ethnography of the Imagined and the Imaged (Langhorne, PA: Harwood Academic Publishers, 1993) 45-84.

Sobchack, Vivian C. "Surge and Spendor: A Phenomenology of the Hollywood Historical Epic," Representations 29 (1990) 24-49.

Späth, Thomas. "Faits de mots et d'images. Les grands hommes de la Rome ancienne," Traverse 5 (1998) $35^{-5}$.

Szondi, Peter. Die Theorie des bürgerlichen Trauerspiels im 18. Jahrhundert: der Kaufmann, der Hausvater und der Hofmeister (Frankfurt am Main: Suhrkamp, 1973).

Tasker, Yvonne. Spectacular Bodies: Gender, Genre and the Action Cinema (London: Routledge, 1993).

Trice, Ashton D., and Samuel A. Holland. Heroes, Antiheroes and Dolts: Portrayals of Masculinity in American Popular Films, 1921-1999 (Jefferson, NC: McFarland, 2001).

Tröhler, Margrit, and Henry M. Taylor. "De quelques facettes du personnage humain dans le film de fiction," Iris 24 (1997) 33-57.

Turconi, Davide. "I film storici italiani e la critica americana dal 1910 alla fine del muto," Bianco e Nero 24 (1963) 40-56.

Urbainczyk, Theresa. Spartacus (London: Bristol Classical Press, 2004).

van Hooff, Anton J. De vonk van Spartacus. Het voortleven van een antieke rebe (Nijmegen: SUN, 1993).

Vanoye, Francis. Scénarios modèles, modèles de scenarios (Paris: Nathan, 1991).

Ward, C. Osborne. The Ancient Lowly. A History of the Ancient Working People from the Earliest Known Period to the Adoption of Christianity by Constantine 4 (Chicago: C.H. Kerr, 1907).

Weber, Max. "Die Entzauberung der Welt," in Weber, Wissenschaft als Beruf (Stuttgart: Reclam, 1995).

Winkler, Martin M., ed., Spartacus: Film and History (Malden, MA; Blackwell, 2007).

Wyke, Maria. Projecting the Past: Ancient Rome, Cinema, and History (New York and London: Routledge, 1997). 